\title{
Condensing embryology teaching: alternative perspectives
}

This article was published in the following Dove Press journal:

Advances in Medical Education and Practice

\section{Mohammad Hasan \\ Syed Maaz Tariq \\ Syed Ali Haider}

Department of MBBS, Jinnah Sindh Medical University, Karachi, Pakistan
Correspondence: Syed Maaz Tariq Jinnah Sindh Medical University, Rafiqi HJ Road, Karachi 755I0, Pakistan Email maaztariqsyed@gmail.com

\section{Dear editor}

We read the article "Condensing embryology teaching for medical students: can it be taught in 2 hours?" by Kazzazi and Bartlett quite attentively. The authors were successful in mentioning an effective mode of teaching embryology. Embryology is indeed an important subject that forms the base for appreciating anatomy and has immense practical implementations in different parts of medicine, for example, in pediatrics and ENT surgery. However, it is often neglected and is only taught in preclinical years. ${ }^{1}$ The authors proposed a method for teaching embryology splendidly from their perspective; therefore, we felt the need to expand the discussion from the perspective of third-year medical students who have just completed their preclinical years. Hence, we would like to mention few limitations to this study as well.

The extent of relevant embryology being taught in medical schools is one of the undefined regions for over a century. Students consider it a low-yield subject, and therefore, know vaguely of its clinical implementations. In some medical schools around the world, teaching time for embryology has been remarkably reduced. ${ }^{2}$ Embryology has always found itself struggling through to acquire itself an imperative part of the enormous medical curriculum. ${ }^{3}$ In a study, postgraduate trainees were found to be struggling with embryology concepts, which not only affected their diagnoses but their career progress as well, which reflects the dire need for the introduction of efficient methods of teaching embryology. ${ }^{2}$ A study, in which embryology was taught using clinical scenarios and clinical management, proved to be of great help for students in grasping the concepts of the subject and elevates their level of satisfaction. It also leads to an irreproachable grounding in medical students. ${ }^{3}$ Further inclusion of clinically oriented multiple-choice questions (MCQs) at the end of class could prove helpful.

Using three-dimensional models and multimedia to help students visualize the changes and processes going within fetuses would be an evolution in methods of teaching. A remarkable work is done by Moraes and Pereira by collecting clinical histories with their images and movies, using the photographs of newborns with embryologic anomalies and exercising this method to teach embryology. Images of normal and abnormal embryos, fetuses and neonates were also included. ${ }^{4}$

In some regions, though considered unethical by some, using autopsy photographs of newborns and fetuses including embryologic events in different stages of development 
turns out to be comprehensible. ${ }^{5}$ Two-phased teaching would be highly beneficial in which basics are taught in the class and their relation with clinical cases would be taught at the affiliated hospital's pediatric/neonatal surgery units.

As far as limitations are concerned, there should be an MCQ-based test at the end of teaching to assess the taught content. Input of subject specialist to condense the course would further refine the outcomes of these types of studies in future.

Embryology is a subject of immense clinical importance; hence, student's satisfaction must primarily be considered while introducing any method of teaching that will not only help students in indulging with the concepts but also applying them in clinics.

\section{Disclosure}

The authors report no conflicts of interest in this communication.

\section{References}

1. Kazzazi F, Bartlett J. Condensing embryology teaching for medical students: can it be taught in 2 hours? Adv Med Educ Pract. 2017;8:797-806.

2. Hamilton J, Carachi R. Clinical embryology: is there still a place in medical schools today? Scott Med J. 2014;59(4):188-192.

3. Scott KM, Charles AR, Holland AJ. Clinical embryology teaching: is it relevant anymore? ANZ J Surg. 2013;83(10):709-712.

4. Moraes SG, Pereira LA. A multimedia approach for teaching human embryology: development and evaluation of a methodology. Ann Anat. 2010;192(6):388-395.

5. Moraes SG, Reis M, Mello MFS, Pereira LAV. The usefulness of autopsies as a tool for teaching human embryology. Braz J Morphol Sci. 2004;21(3):117-123. 


\section{Authors' reply \\ Fawz Kazzazi \\ Jonathan Bartlett}

School of Clinical Medicine, University of Cambridge,

Cambridge, UK

Correspondence: Fawz Kazzazi

School of Clinical Medicine, University of Cambridge, 37 Grange Road,

Leckhampton House, Cambridge CB2 IRH, UK

Tel +4477542 2005

Email fk276@cam.ac.uk

\section{Dear editor}

We read with interest the response letter by Hasan et al. We must first commend the editor and journal on their great ability to unify the medical community and extend topics for debate internationally.

It is interesting to see such insight from preclinical students on the substantial effect that good knowledge of embryology can have on a medical career. Their words have made us consider the implementation of a "refresher embryology course" for clinical students to ensure that its teaching is cemented. The use of clinical cases will complement this teaching very well.

We are aiming to improve access and understanding of embryology and so we would not want to deter students from the teaching session with any form of assessment. We do understand, however, that this may act as a measure of the success of the course.

The use of existing materials is definitely something we will look to incorporate. Our limitations are to produce such materials, so the prompting of existing work is very much appreciated.

This letter has helped us re-evaluate how to further improve the course and widen the participation in the improvement of embryology knowledge.

\section{Disclosure}

The study was independently run and subsequently endorsed through the student-run university societies. The authors report no other conflicts of interest in this communication.

Dove Medical Press encourages responsible, free and frank academic debate. The content of the Advances in Medical Education and Practice 'letters to the editor' section does not necessarily represent the views of Dove Medical Press, its officers, agents, employees, related entities or the Advances in Medical Education and Practice editors. While all reasonable steps have been taken to confirm the content of each letter, Dove Medical Press accepts no liability in respect of the content of any letter, nor is it responsible for the content and accuracy of any letter to the editor.

\section{Publish your work in this journal}

Advances in Medical Education and Practice is an international, peerreviewed, open access journal that aims to present and publish research on Medical Education covering medical, dental, nursing and allied health care professional education. The journal covers undergraduate education, postgraduate training and continuing medical education including emerging trends and innovative models linking education, research, and health care services. The manuscript management system is completely online and includes a very quick and fair peer-review system. Visit http://www.dovepress.com/testimonials.php to read real quotes from published authors.

Submit your manuscript here: http://www.dovepress.com/advances-in-medical-education-and-practice-journal 